\title{
Перспективы пористого кремния как материала для оптоэлектронных приложений
}

\author{
И. М. Жильцов ${ }^{1)}$, Н.В. Латухина ${ }^{1)}$, Д.А. Лизункова ${ }^{1)}$, Г.А. Рогожина ${ }^{1)}$, М. В. Степихова ${ }^{2)}$ \\ ${ }^{1}$ Самарский национальный исследовательский университет им.академика С.П. Королева, \\ Самара, 443086, Московское шоссе, 34 \\ ${ }^{2}$ ИФМ РАН Нижний Новгород \\ тел:+7 (846)334-5455, факс:+7 (846) 334-5455, эл.nочта: natalat@yandex.ru
}

DOI 10.34077/RCSP2019-69

Интерес к пористому кремнию как материалу оптоэлектроники связан в первую очередь с большой площадью его поверхности и наличием наноразмерных кристаллов в его порах, что делает его перспективным для использования, как в фоточувствительных, так и в люминесцентных структурах [1-4]. Однако широкое применение пористого кремния в электронных устройствах сдерживается из-за сложности в управлении свойствами получаемого пористого слоя, особенно в возможности получить низкоомный материал. Чтобы сделать процесс создания пористого кремния хорошо воспроизводимым, в качестве исходной используют поверхность с заранее заданными центрами порообразования, например, текстурированную, представляющую собой поверхность, заполненную правильными четырехгранными пирамидами, на которой порообразование происходит главным образом на стыках пирамид. При этом, если использовать структуры с уже сформированным p-n-переходом, на вершинах пирамид и в их объеме сохраняется исходный тип и уровень легирования, так что образовавшаяся структура представляет собой матрицу микро-диодов на общей монокристаллической подложке, отделенных друг от друга высокоомными областями пористого кремния. Такие структуры являются стабильными, имеют хорошие электрические свойства

В настоящей работе проведена экспериментальная оценка возможности использовать структуры на основе пористого кремния для фотопреобразователей и светодиодов. Исследованы фотоэлектрические и спектральные характеристики структур с верхним слоем из пористого кремния и пористого карбида кремния, вольт-амперные характеристики и спектры фотолюминесценции структур с пористым кремнием, легированным эрбием. Пористый слой создавался на текстурированной поверхности монокристаллических пластин кремния электролитическим травлением. Для создания p-n-перехода проводилось легирование верхнего слоя фосфором, либо использовались пластины с заранее созданным p-n-переходом. Слой карбида кремния на фотоэлектрических структурах создавался методом химического транспорта в открытой системе твердофазных кремния и углерода газом - носителем водородом в зону эпитаксии с последующим осаждением на поверхность пористого кремния. Для создания люминесцентных структур пористый слой насыщался эрбием из водного раствора.

Проведенные исследования позволяют сделать вывод о перспективности использования пористого кремния для оптоэлектроники. Гетероструктура n-SiC/p-porSi с увеличенной фоточувствительностью в коротковолновой области солнечного спектра расширит спектр фоточувствительности ФЭП и, следовательно, увеличит его эффективность. Образцы структуры porSi:Er имеют хорошие люминесцентные характеристики с максимумом на длине волны 1,55 мкм при комнатной температуре и могут служить основой для создания ИК-светодиодов.

\section{Лumepamypa}

[1] Hyukyong Kwon et al. // ISRN Nanotechnology. Vol. 2011, Article ID 716409.

[2] Latukhina N. et al. // Procedia Engineering. 2015. Vol. 104. P. 157-161.

[3] Ю.А Берашевич и др.// ФТП, 2006,Т.40., Вып.2, С. 240 - 245.

[4] Sokolov S.A et al. // Thin Solid Films. 2014. Vol. 562. P. $462-466$. 